\title{
Satellite tag attachment methods for tracking neonate sea turtles
}

\author{
Katherine L. Mansfield ${ }^{1,2, *}$, Jeanette Wyneken ${ }^{2}$, Daniel Rittschof ${ }^{3}$, Molly Walsh ${ }^{3}$, \\ Chai W. Lim ${ }^{4}$, Paul M. Richards ${ }^{1}$ \\ ${ }^{1}$ Southeast Fisheries Science Center, National Marine Fisheries Service, Miami, Florida 33149, USA \\ ${ }^{2}$ Department of Biological Sciences, Florida Atlantic University, Boca Raton, Florida 33431, USA \\ ${ }^{3}$ Nicholas School of the Environment, Duke University Marine Laboratory, Beaufort, North Carolina 28516, USA \\ ${ }^{4}$ Pratt School of Engineering, Duke University, Durham, North Carolina 27708, USA
}

\begin{abstract}
Significant gaps exist in our understanding of early sea turtle life stages. Dispersal and habitat use of young oceanic sea turtles are largely inferred. Historically, available tracking technology and tag attachment methods were limited by small body sizes and rapid growth of neonate sea turtles. We tested methods in the laboratory for attaching small solar-powered satellite tags to neonate loggerhead sea turtles Caretta caretta, including harnesses, hard epoxy and neoprene-silicone mounts. Non-harness attachments were tested on turtles with clean carapaces and carapaces treated with an acrylic base-coat. Turtle growth and condition were measured among treatment and control groups. We tested surrogate solar cells, coated with clear silicone antifoulant for biofouling and performance, and field tested the performance of 7 solar-powered satellite tags on neonate loggerheads released off southeastern Florida (USA). Attachments with acrylic base-coats remained affixed 4- to 8-fold longer than on untreated carapaces. Harness attachments resulted in long-term tag retention (>60 d). However, harness and hard epoxy attachments did not adjust for turtle growth; we do not recommend these methods for rapidly growing neonate turtles. The method with longest retention was a neoprene-silicone attachment on an acrylic base-coat. Growth and condition were comparable among treated and control turtles using this flexible neoprene-silicone-acrylic attachment. Field-tested tags transmitted for 38 to $172 \mathrm{~d}$. There were significant differences in charge rates of tags treated with an antifoulant and untreated tags; however, all tags charged optimally and transmitted high-quality locations. Our data suggest that small solar-powered tags are viable tools for monitoring the in-water behavior of oceanic sea turtles.
\end{abstract}

KEY WORDS: Caretta caretta - Oceanic stage sea turtles $\cdot$ Lost years $\cdot$ Remote tracking Solar-powered satellite tags $\cdot$ Telemetry $\cdot$ Transmitter attachment methods

\section{INTRODUCTION}

Sea turtles are highly migratory marine species that occur in geographically diverse habitats during different ontogenetic stages. Population recruitment begins when hatchlings enter the ocean; however, significant gaps exist in our understanding of early sea turtle life history, and fine-scale migration and location data are lacking for these youngest life stages. To meet recovery goals for these endangered and threatened species, the status and condition of sea turtle stocks must be understood across all life stages (TEWG 2000, Heppell et al. 2005). While the life history of the loggerhead Caretta caretta is the best understood among marine turtles, post-hatching and oceanic stage sea turtle dispersal, in-water habitat use, and survivorship have been largely inferred rather than directly observed (Bolten 2003). 
Empirical data based on opportunistic in-water and stranding observations, phylogeographic studies, and laboratory-based orientation studies indicate that loggerhead hatchlings emerging from nests in the western North Atlantic enter oceanographic current systems that entrain them within the North Atlantic gyre (Brongersma 1968, 1972, 1982, Carr 1986, 1987, Bolten et al. 1992, 1998, Musick \& Limpus 1997, Hays \& Marsh 1997, Lohmann et al. 2001). These turtles remain offshore for several years, undergoing long trans-oceanic migrations, until they settle in tropical, subtropical, and temperate neritic waters within the Atlantic, Mediterranean, Gulf of Mexico, and Caribbean. As larger neritic juveniles, they move within and among feeding grounds and seasonal habitats, foraging on benthic organisms (Musick \& Limpus 1997, Mansfield et al. 2009). Some neritic juveniles return to an oceanic environment for extended periods (McClellan \& Read 2007, Mansfield et al. 2009). Mature loggerheads migrate among neritic or oceanic foraging, breeding, and nesting grounds (Hopkins-Murphy et al. 2003).

Historically, hatchling and neonate tracking studies were directly limited by a lack of suitable small-scale tracking technologies capable of remotely recording the animals' positions over a longer term: weeks to months. Existing data are few and based on laborintensive observations within near-shore habitats. Liew \& Chan (1995) radio-tracked leatherback Dermochelys coriacea hatchlings off the Malaysian Peninsula, but the tag sizes were large enough to bias behavior. Frick (1976) swam after green turtle Chelonia mydas hatchlings a few kilometers from Bermuda's beaches. Ireland et al. (1978) acoustically tracked green turtles up to a few hours as they dispersed from beaches off Tortuguero, Costa Rica. With the exception of a small sample of loggerhead hatchlings followed from shore for up to $3 \mathrm{~d}$ (Witherington 1995), most post-hatching loggerhead tracking studies have covered brief periods: a few hours or less (Witherington \& Salmon 1992, Stewart \& Wyneken 2004, Whelan \& Wyneken 2007). Thus, our understanding of early migratory paths and behavior of sea turtles is limited in sample size, and in spatial and temporal scope.

To remotely monitor young oceanic stage turtles, tracking devices must be small, lightweight, have reduced drag profiles, and attachments must not hinder the turtles' growth, movements, or behavior. Sea turtle growth during their first weeks to months at sea can be rapid (Davenport \& Scott 1993, Bjorndal et al. 2000, Stokes et al. 2006). Stokes et al. (2006) noted an approximate 3- to 5-fold increase in loggerhead mass under controlled laboratory conditions during the first 3 mo post-hatching. Growth rates for similarly aged turtles in the wild are unknown; however, these rates likely vary in naturally stochastic environments due to variable food availability and intake, and thermal variability (Bjorndal et al. 2003). Developing appropriate tagging technology and attachment methods that accommodate growth for young sea turtles (>20 cm carapace length) would provide insight into the turtles' in-water movements and dispersal routes, and aid in the identification of neonate habitats and developmental areas. Such data would contribute to estimates of the energetic costs incurred by these animals while in their oceanic habitats.

We tested the efficacy of small-scale, solar-powered satellite tags for use on neonate loggerhead sea turtles in a marine environment. Upon entering the ocean, post-hatchling loggerheads tend to remain near the sea surface (Musick \& Limpus 1997, Witherington 2002, Bolten 2003). After their first days in the ocean, they associate with flotsam and downwelling lines, exhibiting reduced locomotor activity after the initial frenzy period (Caldwell 1968, Wyneken \& Salmon 1992, Witherington 2002, Wyneken et al. 2008). Due to their surface habitat use, neonate loggerheads are excellent candidates for small-scale, solar-powered tags. These tracking devices were designed for terrestrial bird species and have not been tested on marine animals or in a marine environment.

The present study tested satellite tag attachments, tag antifouling methods, and tag performance with the goal of remotely tracking neonate loggerhead sea turtles. Our objectives were to (1) assess whether traditional methods of attaching tracking devices to larger sea turtles are appropriate for smaller, fastgrowing neonate sea turtles; (2) develop and test novel alternative attachments for neonate loggerhead sea turtles; (3) test clear, silicone-based coatings on solar cell performance; and (4) field test and assess the performance of small-scale, solar-powered satellite tags attached to neonate loggerhead sea turtles released at sea. Here, we identify a low-impact transmitter attachment method to track small ( $>13 \mathrm{~cm}$ carapace length) loggerhead sea turtles for weeks to months in the wild.

\section{MATERIALS AND METHODS}

\section{Study animals}

Hatchling loggerhead sea turtles Caretta caretta were obtained from nests in Boca Raton, Florida, USA $\left(26.42^{\circ} \mathrm{N}, 80.03^{\circ} \mathrm{W}\right)$. Turtles were raised at the 
Florida Atlantic University Marine Laboratory following protocols detailed by Stokes et al. (2006). Briefly, turtles were housed in flow-through seawater tanks maintained at $26^{\circ} \mathrm{C}\left( \pm 2^{\circ} \mathrm{C}\right)$, fed 8 to $11 \%$ of their bodyweight in food daily, and provided with a fixed $12 \mathrm{~h}$ light:12 h dark photocycle. Turtles were reared to minimum weights of $\geq 300 \mathrm{~g}$ (4 to 6 mo old), ensuring that the experimental tags were $\leq 5 \%$ of the turtles' weight, following guidelines designed to minimize the energetic and hydrodynamic costs to tagged animals (Murray \& Fuller 2000).

\section{Tag attachment trials}

Attachment methods for Microwave Telemetry's PTT-100 9.5 g solar-paneled satellite bird tags and equivalent dummy tags were tested for attachment duration and to assess overall costs to the turtles. The manufacturer pressure-proofed and modified the tags with clear epoxy to protect them in a marine environment. The total weight (in air) of each modified tag was approximately 11 to $13 \mathrm{~g}$ (dimensions: $38 \mathrm{~mm}$ length $\times 17 \mathrm{~mm}$ width $\times 12 \mathrm{~mm}$ height). We tested 2 tag attachment approaches: 4 direct carapace attachments using different adhesives and 2 indirect (harness) attachments.
(2) Neoprene-silicone mount: Two strips (approximately $40 \mathrm{~mm}$ length $\times 5 \mathrm{~mm}$ width) of $5 \mathrm{~mm}$ neoprene wetsuit material were glued on either side of the turtle's vertebral ridge (Fig. 1b) using surgical or cosmetic cyanoacrylate adhesives (e.g. 3M VetBond $^{\mathrm{TM}}$ and OnRite ${ }^{\mathrm{TM}}$ Perma Rite \#9 Plus Hard Bond). Approximately 15 to $22 \mathrm{ml}$ of clear All-Glass ${ }^{\mathrm{TM}}$ aquarium silicone was used to affix the dummy tag to the neoprene and shell (Fig. 1c) and to shape a streamlined surface around the attachment site (Fig. 1d).

(3) Hard epoxy mount with acrylic base-coat: We tested PowerFast ${ }^{\mathrm{TM}}$ epoxy, another traditional hard epoxy formerly used in telemetry studies of larger turtles (Girard et al. 2009, Mansfield et al. 2009, Seney et al. 2010). This epoxy was placed over scutes that were first treated with a base-coat of manicure acrylic (Kiss ${ }^{\circledR}$ Acrylic Fill Kit, Kiss Products), applied per the manufacturer's instructions. Turtles' shells were sanded and cleaned as described above. The acrylic mixture was 'painted' on the turtles' shells, thinly covering vertebral scutes I to IV and part of the adjacent costal scutes (Fig. 2a). When dry, we attached the dummy tags directly on top of the acrylic, using 15 to $22 \mathrm{ml}$ of PowerFast ${ }^{\mathrm{TM}}$ epoxy.

(4) Neoprene-silicone mount with acrylic base-coat: Neoprene-silicone mounts (Attachment Method 2) were attached to turtle carapaces pre-treated with an acrylic base-coat as described above (Fig. 2).

\section{Direct attachment methods}

Tags and adhesives were aligned on the carapace, overlapping vertebral scutes I to IV, and slightly overlapping the adjacent costal scutes. The carapace was lightly sanded (Fig. 1a), cleaned using $70 \%$ isopropanol, and allowed to air dry. We then treated the carapace with a $2 \%$ chlorhexidine diacetate disinfectant solution and air dried again prior to tag attachment. Tag antennae were positioned cranially. Attachments tested included:

(1) Hard epoxy mount: We directly attached dummy tags to turtle carapaces using Sonic Weld ${ }^{\mathrm{TM}}$ putty epoxy. This epoxy has been used in other studies to attach satellite tags to larger sea turtles (Mansfield et al. 2009). Approximately 15 to $22 \mathrm{ml}$ of sonic weld epoxy was applied over the vertebral scutes to directly attach tags.

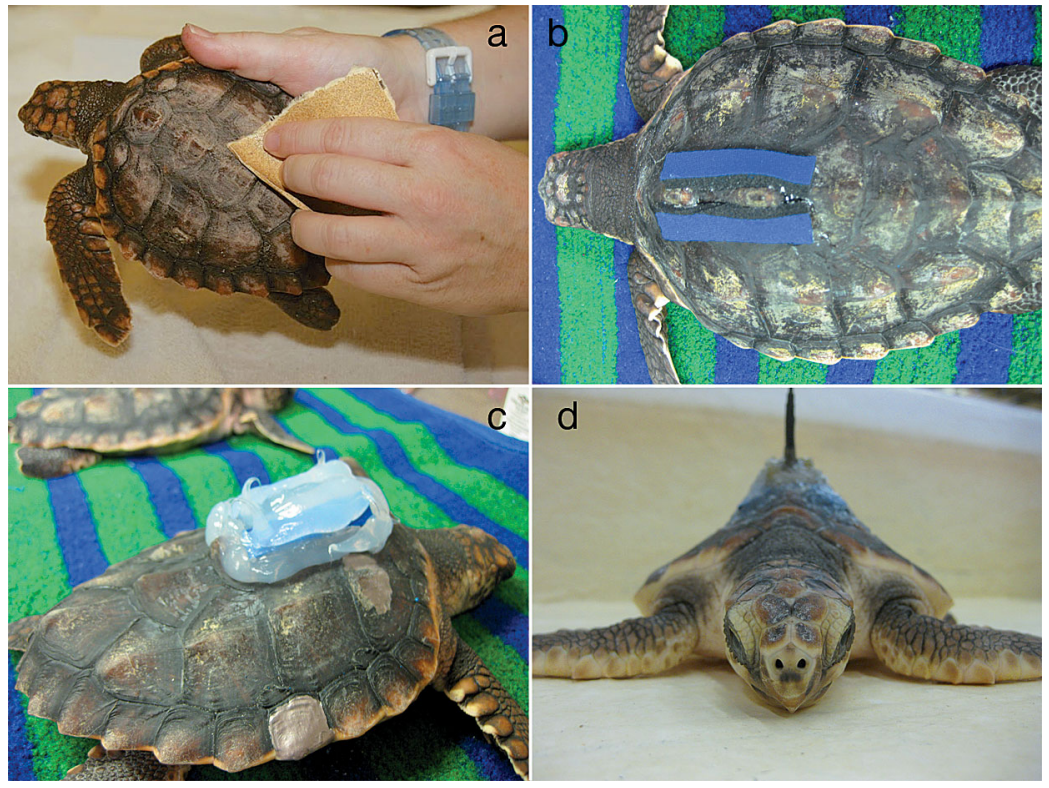

Fig. 1. Procedure for attaching transmitters using a neoprene-silicone mount: (a) sanding carapace at attachment site, (b) attachment of neoprene strips adjacent to vertebral ridge, and (c) addition of aquarium silicone to affix tag. (d) Anterior view of final neoprene-silicone mount 


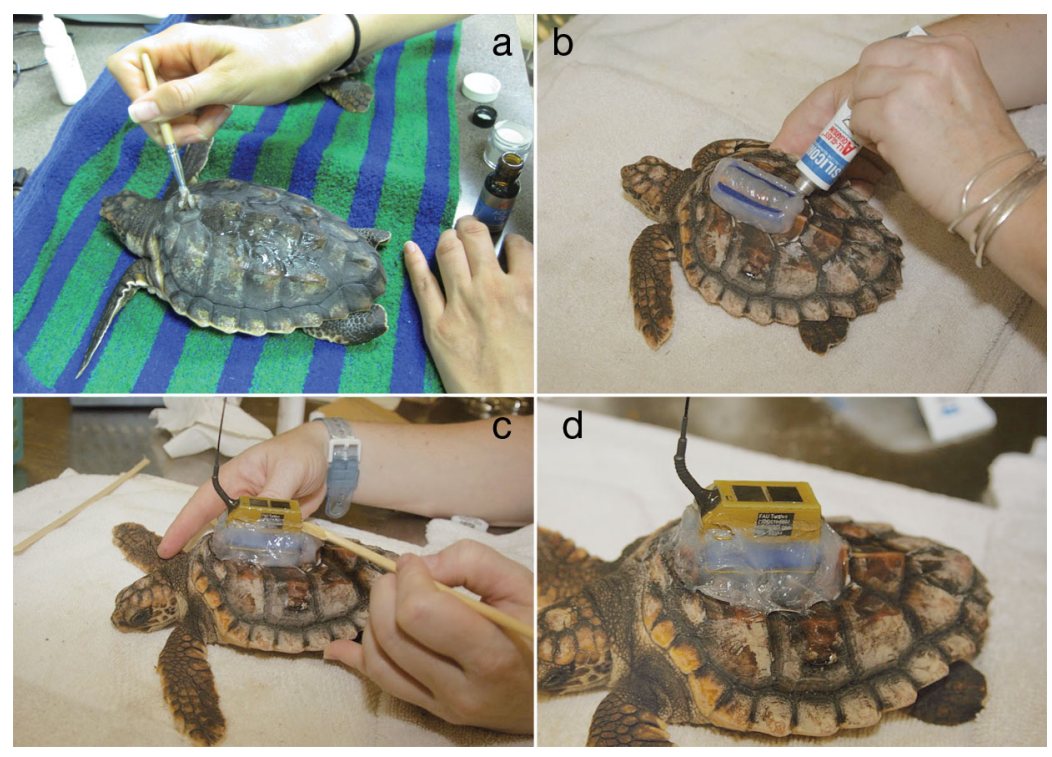

Fig. 2. Attachment process for acrylic base-coat with neoprene-silicone mount: (a) application of acrylic base-coat, (b,c) affixing tag over neoprene strips using aquarium silicone, and (d) final tag attachment

\section{Indirect attachment harness methods}

We developed and tested several harness attachments modified from a 'singlet' design (after Salmon $\&$ Wyneken 1987) used for tethering turtles for activity and orientation studies. These designs form a 1piece 'sleeveless/legless' body harness (Fig. 3). Harness materials tested included:

(5) Lycra $^{\mathrm{TM}}$ and Velcro $^{\mathrm{TM}}$ harness: We tested Lycra $^{\mathrm{TM}}$ swimsuit fabric with breakaway Velcro ${ }^{\mathrm{TM}}$ hook-and-loop closures. We developed a 'singlet' design with small posterolateral 'straps' that secured the harness posterior to the widest aspect of the carapace and positioned dummy tags dorsomedially, leaving the hind flippers and tail free (Fig. 3a).

(6) Lycra $^{\mathrm{TM}}$ and Velcro ${ }^{\mathrm{TM}}$ harness with suture material: We tested the above singlet design with addi-
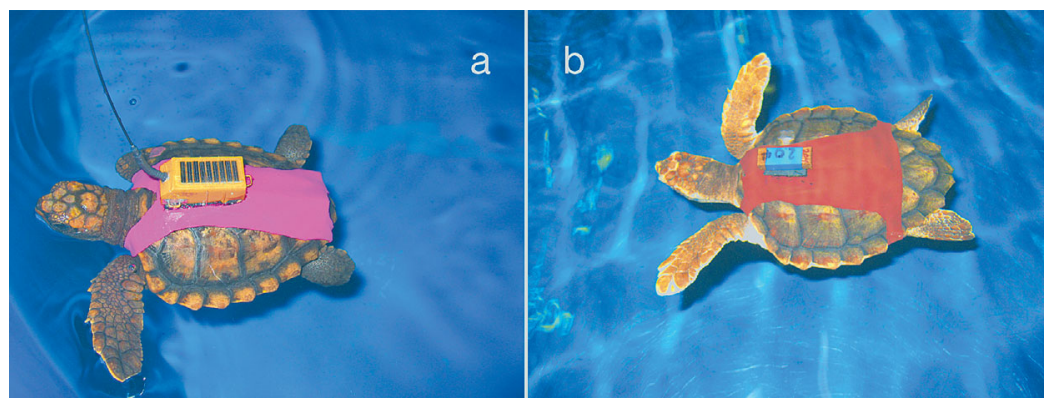

Fig. 3. Examples of indirect harness attachments modified from a 'singlet' design (after Salmon \& Wyneken 1987): (a) Lycra ${ }^{\mathrm{TM}}$ and Velcro ${ }^{\mathrm{TM}}$ harness with post-lateral straps and (b) Lycra ${ }^{\mathrm{TM}}$ and Velcro ${ }^{\mathrm{TM}}$ harness with suture material and with straps located cranially to the inguinal fossa tional break-away points sewn into the fabric using dissolvable surgical veterinary suture material. We modified the posterior straps to wrap around the carapace just cranial to the inguinal fossa (the cavity where the hind limb enters the body; Fig. 3b).

Up to 5 replicates of each attachment method were tested initially; we compared turtles fitted with the experimental attachments to control turtles. All turtles were housed under the same laboratory conditions and fed the same diet. Turtles were monitored daily for changes in buoyancy, diving ability, tag stability, and for damage/abrasion caused by attachment materials. Criteria for rejecting any of the experimental attachment methods included (1) inability to feed; (2) lack of in-water stability or buoyancy control (sustained for $>30 \mathrm{~min}$ ), altered swimming, and/or diving ability (sustained for $>1 \mathrm{~d}$ of observation), and/or abnormal locomotor kinematics; (3) persistent changes in carapace shape due to attachments; (4) short ( $<3 \mathrm{wk})$ attachment durations; (5) change in growth or body condition index $\left(\mathrm{CI}_{i}\right.$ measurements described below) relative to the control group. If any of these criteria were met, the tags and associate attachment materials were removed, the turtles' carapaces cleaned, and the attachment method rejected.

\section{Growth study}

The tag attachment method(s) which were accepted in the initial trials (described above) were tested again during an expanded study where changes in turtle growth over time among treatment turtles ( $n=9$ ) were compared to changes in growth among a treatment-free control group $(\mathrm{n}=11)$. Turtles were measured and weighed within $24 \mathrm{~h}$ of nest emergence; measurements were repeated weekly for the duration of the study. Linear measurements of size were made using vernier calipers to the nearest $0.05 \mathrm{~mm}_{\text {; }}$ standard (notch to tip) straight carapace length (SCL) and width (SCW) were recorded. Mass ( $\mathrm{g}$ $\mathrm{wk}^{-1}$ ) and linear measures $\left(\mathrm{mm} \mathrm{wk}^{-1}\right.$; SCL, SCW) were used to quantify absolute growth of turtles in control and 
experimental groups (body weight was calculated minus the tag and attachment weight). Body condition indices for each turtle were calculated using CI as a function of $M L^{-1}$ (where $M$ is mass in $\mathrm{g}$ and $L$ is $\mathrm{SCL}$ in $\mathrm{mm}$ ). We used a repeated-measures analysis of variance (RM ANOVA) to determine whether there was a significant change in sea turtle growth rate or condition when satellite tags were attached. All turtles' ages in days were converted to ages in weeks to standardize time to a fixed effect (turtles were measured on the same calendar day but differed in age at the time of measurement).

\section{Tag protection}

Silicones are used as anti-corrosive insulators for electrical wires and as antifoulants. Dow Corning T2 Silastic $^{\mathrm{TM}}$ (hereafter termed T2) is a transparent silicone coating used experimentally in studies to deter biofouling organisms (Holm et al. 2005, Rittschof et al. 2008). Many silicones, and T2 specifically, release components that interfere with the polymerization of barnacle glue (Rittschof et al. 2008). We tested the effects of T2 coatings on the charging efficiency and for the prevention of corrosion and biofouling of the solar-powered tags, using surrogate solar cells (Plastics Co. WB-15; $20 \mathrm{~mm} \times 20 \mathrm{~mm}$ ) that were comparable to the cells on the tags.

\section{Testing for energy output}

Nine surrogate solar cells were used to test the effects of T2 silicone coating on solar cell performance, tag corrosion, and fouling. Wire ribbons $(2 \mathrm{~cm}$ long) were soldered to the solar cells using Amtech ${ }^{\mathrm{TM}}$ soldering paste (NWS-4100); the wire ribbons were attached to an M2625 Elenco ${ }^{\circledR}$ voltmeter to measure voltage and current output. Prior to treatment, initial voltage and amperage output for all solar cells were recorded to ensure that the cells were capable of conducting and producing energy. We coated the surrogate cells with $\mathrm{T} 2$, mixed in accordance with the manufacturer's instructions and placed in a vacuum for de-gassing prior to use. Three control cells were left uncoated, 3 cells were single-coated, and 3 cells were doubled-coated. Coated cells were de-gassed and placed in a $70^{\circ} \mathrm{C}$ oven until cured. We tested the energy output of cells using a continuously illuminated incandescent lamp with a $52 \mathrm{~W}$ bulb (at a distance of $55 \mathrm{~cm}$ ) as the light source. We recorded the power output (W) generated for each cell.
Power output when submerged

To determine whether the silicone coating interfered with power output of surrogate solar cells while in water, the power output (W) of 2 control cells, 3 single-coated cells, and 3 double-coated cells were tested, both out of water and submerged in seawater. Insulated wires were attached to the cells to suspend them at depth (up to $1 \mathrm{~m}$ ) and to deliver energy output. Output of cells in air was determined by exposing them to a continuously illuminated $52 \mathrm{~W}$ bulb positioned $55 \mathrm{~cm}$ from the test cells. For measurements in water, a $52 \mathrm{~W}$ bulb was placed $20 \mathrm{~cm}$ from the water surface. Cells were submerged at $5 \mathrm{~cm}$ intervals (from 5 to $30 \mathrm{~cm}$ depth). Energy output was recorded as amps and volts; power is reported as watts with $95 \%$ confidence limits (CL).

\section{Corrosion test}

To test if T2 prevented solar cell corrosion, each of the 3 treatment groups was isolated in separate glass dishes and completely submerged (with the exception of wires for power measurements) in $30 \mathrm{ml}$ of seawater for $6 \mathrm{~d}$.

\section{Short-term antifouling}

To test the antifouling capabilities of T2, solar cells ( $\mathrm{n}=3$ control, 3 single-coated, 3 doublecoated) and a Microwave Telemetry $9.5 \mathrm{~g}$ dummy tag were attached to a metal screen with a PVC pipe frame. This apparatus was suspended off the research dock at the Duke University Marine Laboratory (DUML) in Beaufort, North Carolina (USA), and observed in the field for $6 \mathrm{~d}$ in June 2009. Fouling at this time, though variable, is intense enough that one can assess the antifouling nature of the coatings (Roberts et al. 1991). The control and experimental coatings could not be directly compared because the coating dramatically changes the surface characteristics of the solar cells from hydrophilic to lipophilic, which determines, over short time intervals, the kinds of organisms that will colonize the surface (Roberts et al. 1991). The singleand double-coated surfaces are comparable since they have the same surface characteristics, but differ in the amounts of compounds leaching from the coatings. Treatments were examined under a dissecting microscope every $24 \mathrm{~h}$. 


\section{Tag performance}

We deployed 7 active satellite tags on laboratoryreared neonate loggerhead turtles. Tags were attached 24 to $36 \mathrm{~h}$ in advance of release to allow for a $24 \mathrm{~h}$ acclimation period in the laboratory, during which time the turtles were observed to ensure they were capable of diving, foraging, and maintaining buoyancy control. Turtles were released in the Gulf Stream (Table 1) on May 9, 2009 ( $\mathrm{n}=2$ females), June 12, 2009 ( $\mathrm{n}=3$ females), and December 14, 2009 ( $\mathrm{n}=2$; 1 female, 1 male), 10 to $15 \mathrm{~km}$ offshore of Riviera Beach, Florida (USA). All tags were configured with a $10 \mathrm{~h}$ on, $48 \mathrm{~h}$ off duty cycle to allow for full battery charging. Transmitter data (location, battery voltage) were collected by Service ARGOS. Location data were characterized by ARGOS into location class (LC) codes 3, 2, 1, 0, A, and B (listed in order of declining location accuracy; CLS America 2007). ANOVA was used to test for differences in daily battery voltage rates between tags treated with the antifoulant T2 ( $\mathrm{n}=5 ; 374 \mathrm{~d})$ and those left untreated $(\mathrm{n}=2$, May 9 release; $117 \mathrm{~d})$.

\section{RESULTS}

\section{Tag attachment trials}

Direct attachment methods - no acrylic base-coat

Dummy tags attached with the hard epoxy Sonic Weld $^{\mathrm{TM}}(\mathrm{n}=5)$, remained on the turtles for an average $( \pm \mathrm{SD}$ ) of $19 \pm 12.6 \mathrm{~d}$ (range: 3 to $36 \mathrm{~d}$ ). The tag-carapace 'seal' loosened within an average of $5.4 \pm 1.82 \mathrm{~d}$ (range: 3 to $8 \mathrm{~d}$ ). The neoprene-silicone treatment remained on turtles' carapaces for an average of $16.8 \pm$ $4.21 \mathrm{~d}$ (range: 11 to $21 \mathrm{~d}$ ), with the silicone-carapace seal loosening after 8 d (i.e. the tags delaminated from the turtles' shells, forming visually detectable space between the attachment material and carapace). A very thin layer of sloughed keratin was found attached to the base of all attachments at the time the tags detached from the turtles' shells.

Direct attachment methods with acrylic base-coat

Among turtles with carapaces treated with an acrylic base-coat, the PowerFast ${ }^{\mathrm{TM}}$ hard epoxy ( $\mathrm{n}=$ $3)$ and neoprene-silicone mounts $(n=3)$ remained attached in the laboratory for a minimum of 50 to $66 \mathrm{~d}$. Turtles quickly adjusted to these attachments and were observed feeding, diving, swimming, and maintaining orientation and buoyancy control with no observable difficulty. Per our permit specifications, we were required to remove attachments and release these turtles (treated with the acrylic basecoat) before all could naturally shed the dummy tags. The hard PowerFast ${ }^{\mathrm{TM}}$ epoxy-acrylic attachment temporarily altered the shape of the turtles' carapaces, causing a slight straightening of the carapace along the midline at the site of attachment. This distortion effect was noted only when tags were removed. Shells returned to their natural shape within $24 \mathrm{~h}$ of tag removal; the effect was not permanent. Some peeling of the acrylic base-coat occurred after 9 to $12 \mathrm{~d}$, but did not impair the attachment duration. Regardless, non-flexible hard epoxy attachments were rejected due to the potential to alter carapace shape as the turtle grows. No carapace anomalies were noted when the flexible neoprene-silicone attachments were removed. The least consequential and longest lasting directattachment method was a neoprene-silicone attachment with acrylic base-coat.

Table 1. Caretta caretta. Summary data for field-tested satellite tags and tracked turtles, including turtle identification number (ID), straight carapace length (SCL), total weight, body depth, sex (female/male), whether tags were treated with antifoulant (T2 Silastic ${ }^{\mathrm{TM}}$ ) prior to release (yes/no), age of turtle, hatch date, release date, and track duration from release location

\begin{tabular}{|c|c|c|c|c|c|c|c|c|c|}
\hline $\begin{array}{l}\text { Turtle } \\
\text { ID }\end{array}$ & $\begin{array}{l}\mathrm{SCL} \\
(\mathrm{mm})\end{array}$ & $\begin{array}{l}\text { Weight } \\
\text { (g) }\end{array}$ & $\begin{array}{l}\text { Body depth } \\
\text { (mm) }\end{array}$ & Sex & $\begin{array}{c}\text { Treatment } \\
\text { with antifoulant }\end{array}$ & $\begin{array}{l}\text { Age } \\
\text { (d) }\end{array}$ & $\begin{array}{l}\text { Hatch } \\
\text { date }\end{array}$ & $\begin{array}{l}\text { Release } \\
\text { date }\end{array}$ & $\begin{array}{c}\text { Track } \\
\text { duration (d) }\end{array}$ \\
\hline 92584 & 149.5 & 537 & 71.4 & F & $\mathrm{N}$ & 214 & 7 Oct 2008 & 9 May 2009 & 38 \\
\hline 92585 & 182.8 & 615 & 75.9 & $\mathrm{~F}$ & $\mathrm{Y}$ & 251 & 4 Oct 2008 & 12 Jun 2009 & 59 \\
\hline 92586 & 133.5 & 364 & 55.6 & M & $\mathrm{Y}$ & 127 & 10 Aug 2009 & 15 Dec 2009 & 38 \\
\hline 92587 & 163 & 721 & 77.8 & $\mathrm{~F}$ & $\mathrm{Y}$ & 251 & 4 Oct 2008 & 12 Jun 2009 & 55 \\
\hline 92588 & 169 & 692 & 78.7 & $\mathrm{~F}$ & $\mathrm{Y}$ & 281 & 4 Sep 2008 & 12 Jun 2009 & 50 \\
\hline 92589 & 146 & 475 & 61.9 & $\mathrm{~F}$ & $\mathrm{Y}$ & 127 & 10 Aug 2009 & 15 Dec 2009 & 172 \\
\hline 92590 & 150 & 577 & 72.5 & $\mathrm{~F}$ & $\mathrm{~N}$ & 247 & 4 Sep 2008 & 9 May 2009 & 79 \\
\hline
\end{tabular}


Indirect attachment methods

Turtles outfitted with harnesses were able to maintain buoyancy control and dive or feed without difficulty. All harness attachments resulted in longterm tag retention; however, they did not adjust for turtle growth, resulting in binding that temporarily altered carapace shape (shape returned to normal in 1 to 3 wk after harness removal). Both break-away designs (Velcro ${ }^{\mathrm{TM}}$ and suture thread), failed to release as the turtles outgrew their harnesses. Thus, we rejected all indirect attachment harness designs tested.

\section{Growth study}

Here we examined growth rates of turtles treated with the neoprene-silicone tag attachment and acrylic base-coat ( $\mathrm{n}=9$ treatment turtles; $\mathrm{n}=11$ controls). This was the only method that met Acceptability Criteria (1) to (4), including attachment longevity. The RM ANOVA found no detectable statistically significant effect of satellite tag attachment on any of the growth measures-SCL (RM ANOVA: $F=0.61, p=0.455), \mathrm{SCW}$ (RM ANOVA: $F=0.3355, \mathrm{p}=0.5784)$, weight (RM ANOVA: $F=0.0194, \mathrm{p}=0.89600)-$ or on condition (RM ANOVA: $F=0.3542, \mathrm{p}=0.5936$ ). As expected, the analysis showed a significant increase of all growth variables as a function of time (e.g. SCL: $F=$ 2005.25, p < 0.001), with no significant interaction effects (tag attachment by age) except for SCL (RM ANOVA: $F=1.459, \mathrm{p}<0.05)$. The significant interaction between SCL growth and treatment suggests that individual growth in SCL was different through time (different slopes) between control individuals and those that had tags attached (Fig. 4). At the time tags were initially affixed to the turtles for the present study, treatment individuals were slightly larger $($ mean $\pm \mathrm{SD} \mathrm{SCL}=12.3 \pm 0.02 \mathrm{~cm}$; range: 4.3 to $4.9 \mathrm{~cm}$ ) than control individuals (mean $\pm \mathrm{SD}$ $\mathrm{SCL}=11.6 \pm 0.1 \mathrm{~cm}$; range: 4.3 to $4.6 \mathrm{~cm})$, but not significantly larger ( $t$-test: $t_{18}=1.66, \mathrm{p}=0.11$ ). For the first few weeks after tag attachment, treatment turtles appeared to show decreased growth in mean SCL rates compared to the controls; however, they later matched control turtle growth rates for the duration of the study. Tags remained affixed to the turtle carapaces between 59 and 123 d (mean \pm $\mathrm{SD}=94.8 \pm 24.9 \mathrm{~d}$ ); treatment turtles grew an average of $3.5 \pm 1.1 \mathrm{~cm}$ (range: 2.2 to $5.1 \mathrm{~cm}$ ) before shedding the tags.

\section{Tag protection}

\author{
Energy output in air and at depth
}

Prior to testing, each solar cell $(\mathrm{n}=9)$ produced between 1.2 and $1.4 \mathrm{~mW}$ when placed $55 \mathrm{~cm}$ from the light source. Power output in the surrogate cells fluctuated over time from about $30 \%$ higher on Day 4 (uncoated) to about $55 \%$ of original output by Day 6 (uncoated). Output fluctuation by single-coated cells was variable ranging from $10 \%$ higher on Day 2 to about $75 \%$ higher on Day 5, as was output by the double-coated cells (10\% higher on Day 2 to about $85 \%$ of the original on Day 5). Output by Day 6 for single- and double-coated cells was $>90 \%$ of original and higher than the output of the uncoated cells on the same day.

Current (amps) was comparable among the coated and uncoated solar cells exposed only to air. Power output changed once cells were submerged in seawater, with a large drop with immersions at depth $(5$ to $10 \mathrm{~cm})$. There was only slight variability $( \pm 0.03 \mathrm{~mW})$ among average output for each group (Fig. 5a). The relative difference in output decreased rapidly with depth to $30 \mathrm{~cm}$, at which depth all outputs were roughly comparable and were approximately one-seventh of the output at $5 \mathrm{~cm}$ depth (Fig. 5b).

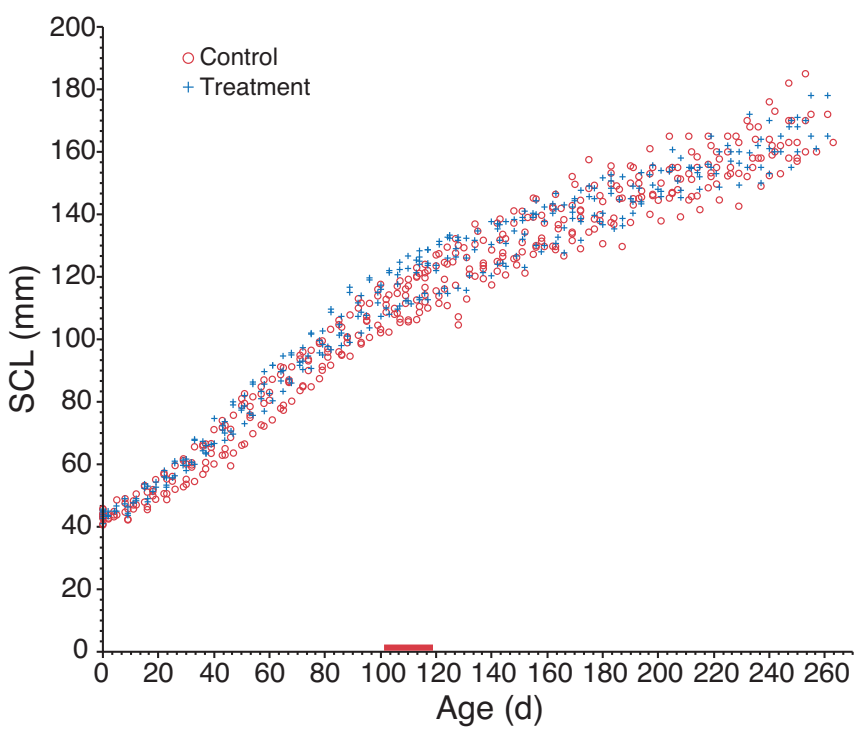

Fig. 4. Caretta caretta. Turtle growth (straight carapace length; SCL) over time (d) for control animals and those with neoprene-silicone-acrylic attachments. Start of attachment trial is indicated by red line on the $x$-axis. Note that the growth study commenced on the same day; however, turtles differed in age at the time of study 

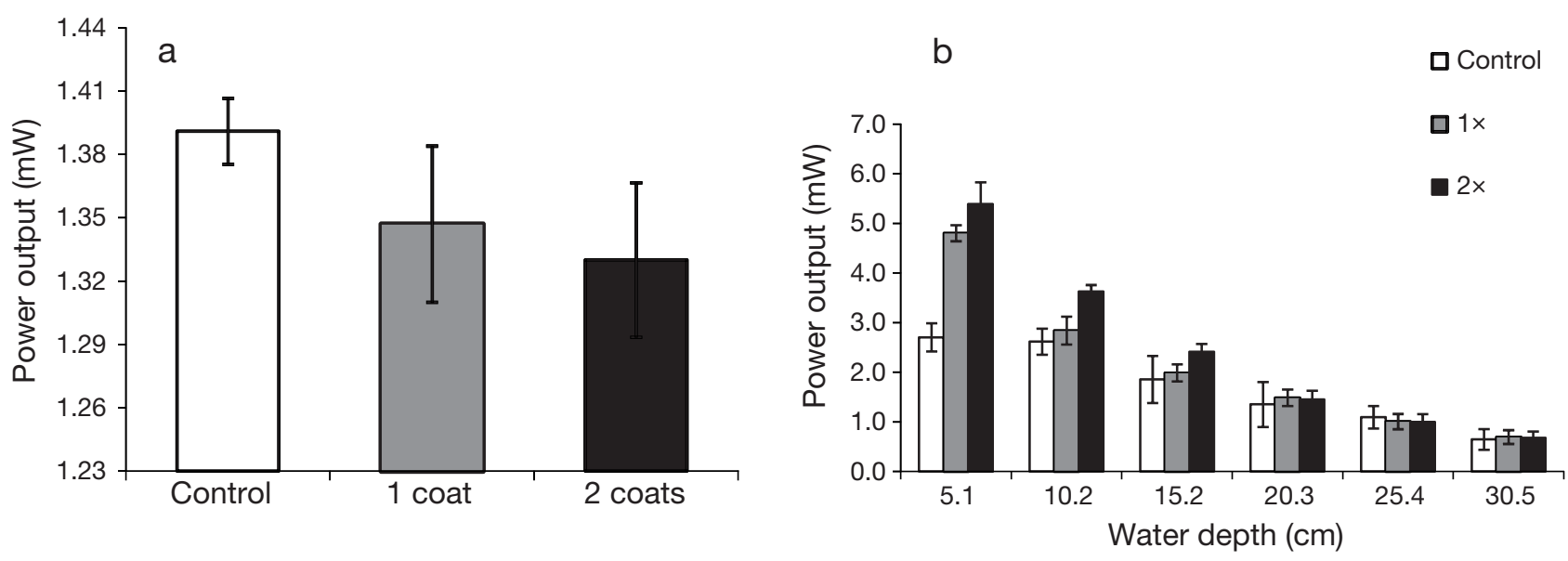

Fig. 5. Solar cell tests. (a) Average power output for treatment groups for control cells and cells treated with 1 (1x) or 2 coats $(2 \times)$ of T2 Silastic ${ }^{\mathrm{TM}}$ and (b) actual power output of surrogate control and treatment (1x and $\left.2 \times\right)$ solar cells at different water depths. Error bars: $1 \mathrm{SD}$

\section{Corrosion test}

Upon continuous exposure to seawater the uncoated cells became visibly corroded, while the coated cells showed no change. In addition, the double-coated Microwave Telemetry tag showed no indication of corrosion after $4 \mathrm{~d}$ of submergence.

\section{Antifouling test}

Barnacles settled on control and treated cells; all barnacles found on the control cell were alive after $6 \mathrm{~d}$. When soft-bodied organisms were found on the treated cells, they disappeared or died within $1 \mathrm{~d}$. Bryozoans Bugula neritina, low surface-energy organisms, settled and grew on single-coated surfaces during Days 1 and 2. Bryozoans were observed on all replicates; however, every bryozoan we observed to settle on the single-coated surfaces died the day after settlement. From Days 3 to 6, five barnacles settled on the single-coated surfaces, 1 of which died. B. neritina were not observed growing on the double-coated surfaces - only a single encrusting bryozoan settled and died. No other sessile organisms settled on the double-coated surface until Day 6, when 3 barnacles settled on 1 replicate and 1 barnacle settled on a second. One of the 3 barnacles that settled on the first replicate was dead at the time of observation.

\section{Tag performance in the field}

All tags transmitted for at least $38 \mathrm{~d}$. At release, turtles had an average $( \pm \mathrm{SD}) \mathrm{SLC}$ of $15.6 \pm 1.6 \mathrm{~cm}$ (range: 13.4 to $18.3 \mathrm{~cm}$ ) and weighed $586.6 \pm$ $123.9 \mathrm{~g}$ (range: 364 to $721 \mathrm{~g}$ ) (Table 1). Tags transmitted for an average of $70.1 \mathrm{~d} \pm 47.0$ (range: 38 to 172 d) (Table 1). Excluding 1 'outlier' tag that transmitted for $172 \mathrm{~d}$, tags ceased transmitting within $80 \mathrm{~d}$ of deployment $(\mathrm{n}=6$; mean $=53.2 \pm$ $15.3 \mathrm{~d}$; range: 38 to $79 \mathrm{~d}$ ). The majority of locations received were LC2 (30.1\%) and LC1 (27.1\%); $>77.2 \%$ of messages received had associated LCs between 0 and 3 (Fig. 6).

There were significant differences in daily charge voltages (V) among tags treated with T2 and those left untreated (ANOVA: $F=380.5$; $\mathrm{p}<0.0001$ ); however, all tags were charging with each duty cycle. Mean $( \pm \mathrm{SD})$ daily charges for untreated tags was $4.12 \pm 0.07 \mathrm{~V}$ (range: 3.4 to $4.4 \mathrm{~V}$ ). Among treated

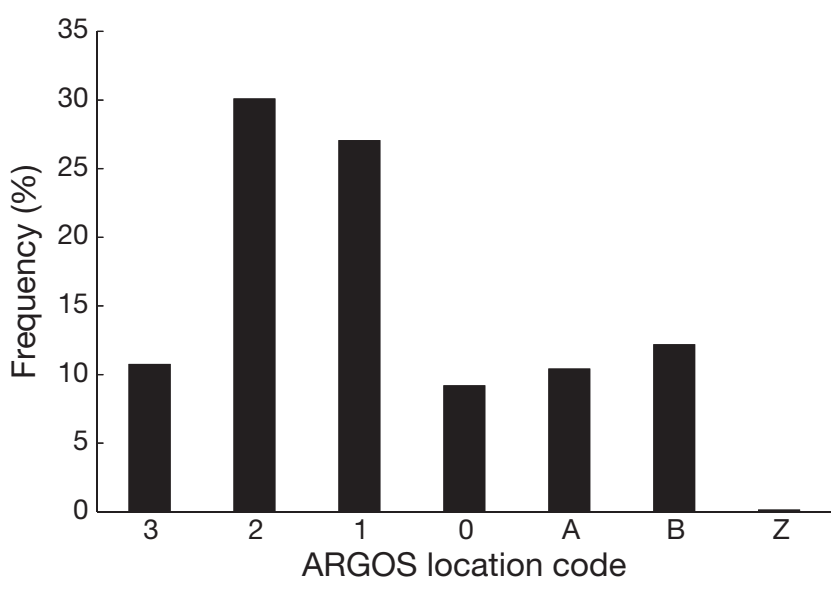

Fig. 6. Caretta caretta. Frequency distribution (percent) of ARGOS location codes received during 38 to $172 \mathrm{~d}$ field deployment periods ( $\mathrm{n}=7$ tags) 
tags, the mean charge was $4.09 \pm 0.07 \mathrm{~V}$ (range: 3.2 to $4.4 \mathrm{~V}$ ). All tags maintained adequate operational (approximately $>3.2 \mathrm{~V}$; Microwave Telemetry, pers. comm.) and optimal mean ( 4.0 V; C. Bykowsky, Microwave Telemetry, pers. comm.) charge rates when transmissions ceased (Fig. 7).

\section{DISCUSSION}

\section{Tag attachment}

We identified 1 tag attachment method that was superior to all others tested: the neoprene-silicone attachment over an acrylic base-coat. It allowed for neonate turtle growth, showed no detectable effects on swimming or diving behavior in a laboratory setting, shed cleanly from the carapace, performed well in the field, and had attachment durations averaging 2 mo. Due to the rapid growth of neonate sea turtles, tag attachment methods using only hard epoxies are not appropriate. Hard substances or harness attachments should be avoided as they may alter carapace shape if not quickly shed. In the United States, harness methods on larger sea turtles, particularly leatherbacks Dermochelys coriacea, are not currently favored due to reports of chafe, abrasion, and the potential for increased hydrodynamic drag (Troëng et al. 2006, Fossette et al. 2008, Sherrill-Mix \& James 2008, Jones et al. 2011).

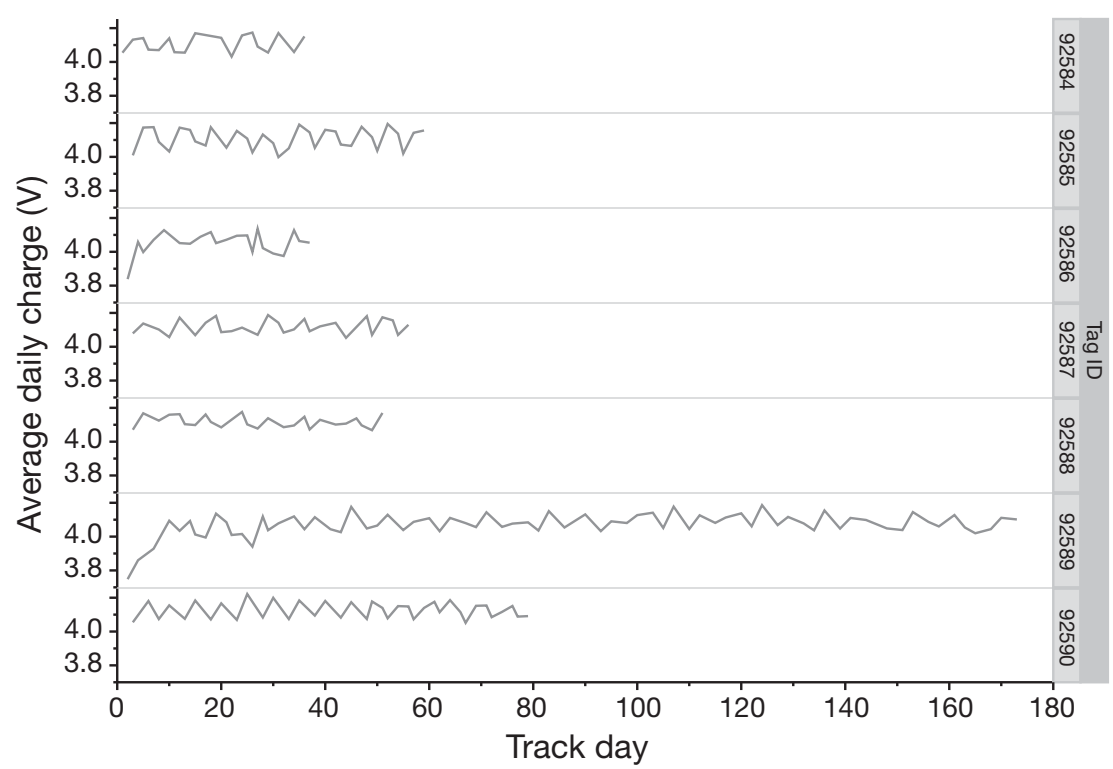

Fig. 7. Average daily charge of solar platform transmitter terminals $(n=7)$ during 38 to $172 \mathrm{~d}$ deployment periods. Lower charges at start of field trials likely reflect lower charge frequency associated with weekly $4 \mathrm{~h}$ charge periods pre-deployment (vs. $48 \mathrm{~h}$ after $10 \mathrm{~h}$ of transmission)
While vertebral ridge profiles make it difficult to attach tags close to the turtle's center of gravity (near the first or second vertebral scutes; Dougherty et al. 2010), we found that gluing small pieces of $5 \mathrm{~mm}$ neoprene to either side of the ridge provided an effective cushion, with the additional benefit of the positively buoyant material somewhat offsetting tag weight. The flexibility of the combined neoprene and silicone attachment allowed for growth to occur without altering carapace shape.

Tag placement is critical for minimizing drag effects and potential locomotor costs. We considered and addressed several issues associated with drag. Watson \& Granger (1998) tested the hydrodynamic implications of anteriorly placed tags and found the higher the profile, the greater the likely energetic cost. Dougherty et al. (2010) showed that the center of gravity of neonate sea turtles is ventral to the first and second vertebral scutes. Mass added behind the center of gravity could shift the center posteriorly and thus change swimming behavior. By positioning tags towards the front of the carapace and smoothing/tapering the silicone, drag is minimized. While we anticipated small expansion of the drag profile, we saw no substantive changes in drag-related costs. Consequences of drag are realized in energetic costs to the turtle. With neonate turtles, energetic costs are manifested in decreased growth; a decline in growth rate or CI associated with tag attachment would reflect added costs. We retained the treatment turtles for a minimum of $2 \mathrm{wk}$ after the tags were shed. Since sea turtles have the potential to regulate food consumption and energy assimilation, such compensation might minimize any potential impact on condition within 1 or $2 \mathrm{wk}$ (e.g. Roark et al. 2009). During our attachment trials, we found no biologically measureable costs associated with the direct neoprene-silicone-acrylic attachment; however, it is possible that a reduction in growth or body size could have occurred later, and, conceivably, other latent effects not considered by our metrics could also emerge (sensu Wilson 2011), particularly under natural field conditions.

The limiting factor for using any tag attachment method is the necessity of accommodating rapid growth and allowing for subsequent shedding of the tags (minimizing long-term risk to the turtle). In all cases, the neoprenesilicone-acrylic mount sheds cleanly, 
leaving no residual attachment material on the carapace. While early laboratory trials indicated that rapid integument turnover can result in early tag shedding, adding an acrylic base-coat extended tag attachment durations by 4 - to 8-fold, allowing for between 2 and $5 \mathrm{~cm}$ in straight carapace growth under laboratory conditions. Thus, the neoprene-siliconeacrylic method provides a smooth, flexible, hydrodynamic surface around the attachment site that allows for normal shell flexion while diving and during subsequent turtle growth.

\section{Tag protection}

The variability in energy output of the treated and untreated solar cells in air was so small that it can be concluded that T2 does not decrease the energy output of the solar cells. When tested under water, there was no decrease in efficiency as a result of T2. After $6 \mathrm{~d}$ of submersion to test for corrosion, the energy output of the untreated solar cells decreased compared to that of the treated solar cells. More specifically, the solar cells treated with 2 coats of T2 produced more energy than did the single-coated cells or the control cells.

T2 did not prevent all biofouling. Some organisms with base plates, such as barnacles, survived. The calcareous base of barnacles protects their soft tissues from the toxic coating (Rittschof 2000). While a more diverse group of organisms was attracted to T2treated solar cells, soft fouling organisms died when in contact with T2 and thus did not have long-term fouling effects. While T2 prevents corrosion of solar cells, it is only somewhat effective in reducing biofouling. We expect that the use of T2 as an antifouling agent could be further improved in combination with another substance such as silicone oil (Rittschof et al. 2008). This initial work allows us to conclude that the double-coated system protects the tag from macrofouling for at least $6 \mathrm{~d}$ in a near-shore coastal environment. Barnacles are among the most aggressive of macrofoulers, and, although they were colonizing the single-coated surface by Day 3, they did not colonize the double-coated surface until Day 6-a timeframe that should be sufficient to enable the turtles to reach waters farther offshore where lower concentrations of surface-fouling larval organisms occur.

\section{Tag performance}

Solar-powered tags are well suited to tracking neonate loggerheads. These turtles tend to remain near the surface and associate with flotsam (e.g. Sargassum), showing little locomotor activity (Caldwell 1968, Witherington 1995, 2002, Smith \& Salmon 2009). Thus, the tags are exposed to air, further minimizing the tags' hydrodynamic drag and suitability for some epibionts. This surface-based habitat use is one of the reasons that solar-powered tags are successful for tracking the at-sea movements of these smaller turtles; the tags require direct sun exposure to maintain a charge over time. This prolonged tag exposure also provides longer windows of communication with overhead satellites, a higher degree of location accuracy (LC 3 to 0; Hays et al. 2001, Tougaard et al. 2008), and ample opportunities to recharge solar cells.

Our data indicate that all tags were fully charging when transmissions ceased, likely indicating that (1) turtles were spending most of their time at the surface as is expected, based on the existing scientific understanding of this stage class; (2) tags were likely shed (vs. ceasing transmissions due to lack of charge); and/or (3) the subject animals were preyed upon. It is possible that some other variable caused each of the tags to suddenly cease transmitting and that the tags remained attached to the turtles after the last transmission was received. As such, the length of tag transmission we observed should be considered a minimum estimate for tag attachment duration under field conditions. The tags and attachments are negatively buoyant, and we expect them to sink after falling off the turtles' shells. The tags are only capable of transmitting if the antennae are exposed to air. Thus, abrupt cessation of transmission suggests the antenna was no longer exposed to air.

\section{CONCLUSIONS AND RECOMMENDATIONS}

These solar-powered tags are newly adapted for marine use and have considerable potential to revolutionize sea turtle in-water research by identifying nursery areas, preferred habitat characteristics, and quantifying the dispersal patterns, potential growth, and offshore movements of neonate sea turtles ( $>11$ to $12 \mathrm{~cm} \mathrm{SCL}$ ). Under field conditions, tags ceased transmitting after an average of $70 \mathrm{~d}$, less than the average attachment duration (approximately $95 \mathrm{~d}$ ) under controlled laboratory conditions. Conditions observed in the laboratory are necessarily different in nutrient availability and lack much of nature's stochasticity. The at-sea levels of ultraviolet light exposure, turbulence, amount of flotsam/jetsam encountered, diving behavior, interactions with other species (including cleaner organisms), fouling rates, 
water temperature, and predation are all factors that may directly or indirectly affect tag performance and attachment duration. While growth rates are likely accelerated in the laboratory, our methods allowed us to successfully track neonate turtles (>13 cm SCL) for at least 2 mo in an open marine environment. Our data also indicate that the neoprene-silicone-acrylic method has a tag attachment duration limited by 2 to $5 \mathrm{~cm}$ in turtle growth (SCL). The growth of poikilotherms is influenced by variability in the thermal environmental and available food (Bjorndal et al. 2003). With a larger growth study coupled with environmental analyses, it may be possible to roughly estimate the size of neonate sea turtles tracked in the wild at the time of tag cessation.

With laboratory and field testing, our attachment method may be applicable to other species of sea turtle and other taxa of surface-dwelling marine animals (e.g. crab species, small marine mammals, marine birds). This method will also be applicable for use with other, newer tag technologies as they are developed in the future. The tags we used in the present study were originally designed for terrestrial birds, not marine organisms. Future tag developers should consider reducing the tags' profile, size, and weight - all factors that would further minimize any impacts of drag or turbulent surface conditions on the turtles. Further study is suggested to better assess the long-term impacts of our methods on turtles, including determining drag profiles for the tags under realistic surface conditions and at different attachment sites on the carapace.

Neonate loggerheads spend considerable time at the sea surface; however, other turtle species may not. Shell flexion, a consequence of diving and vigorous swimming, may weaken the attachment site on other species that dive deeper or with more frequency than neonate loggerheads. We therefore recommend further testing (including laboratory and field studies) before applying these methods to other species of sea turtle.

Our methods provide the first successful satellite tracks of any neonate sea turtle. This work will ultimately improve our understanding of their early dispersal paths and rates, providing in situ behavioral data that will better inform theoretical dispersal models (e.g. Hays et al. 2010). Satellite tracking data from neonate turtles will also improve our understanding of sea turtle oceanic nursery and developmental habitats, contribute to energetic and life-history models, help identify the threats these young turtles may face, and better delineate areas for targeted species management.
Acknowledgements. We especially thank M. Marrero (Not Just Nails, Boynton Beach, Florida, USA). We also thank J. Abernethy (Jim Abernethy's Scuba-Adventures, Lake Park, Florida, USA), L. Bachler, Z. Darnell, S. Epperly, A. Forman (OnRite Co. Inc., Fort Lauderdale, Florida, USA), C. Gonzales, K. Latanich, R. Matyisin, C. Mott, K. Phillips, K. Rusenko, and the Gumbo Limbo Nature Center, E. Stenersen, A. Stiles, and E. Wood. Supplies for this study were provided by OnRite Co. Inc. and parent company Hairloss.com, and Wet Wear Custom Wetsuits (Hallandale, Florida, USA). Funding was provided by the Large Pelagics Research Center Extramural Grants Program, the National Academies Research Associateship Program, Disney Wildlife Conservation Fund, Florida Sea Turtle Grants Program, Save Our Seas Foundation, NOAA Fisheries, Southeast Fisheries Science Center, the Ashwanden Family Fund, the Nelligan Sea Turtle Research Support Fund, and personal funds.

\section{LITERATURE CITED}

Bjorndal KA, Bolten AB, Martins HR (2000) Somatic growth model of juvenile loggerhead sea turtles Caretta caretta: duration of pelagic stage. Mar Ecol Prog Ser 202:265-272

Bjorndal KA, Bolten AB, Dellinger T, Delgado C, Martins HR (2003) Compensatory growth in oceanic loggerhead sea turtles: response to a stochastic environment. Ecology 84: 1237-1249

Bolten AB (2003) Active swimmers-passive drifters: the oceanic juvenile stage of loggerheads in the Atlantic system. In: Bolten AB, Witherington BE (eds) Loggerhead sea turtles. Smithsonian Institution Press, Washington, DC, p 63-78

Bolten AB, Martins HR, Bjorndal KA, Cocco M, Gerosa G (1992) Caretta caretta (loggerhead) pelagic movement and growth. Herpetol Rev 23:116

Bolten AB, Bjorndal KA, Martins HR, Dellinger T, Biscoito MJ, Encalada SE, Bowen BW (1998) Transatlantic developmental migrations of loggerhead sea turtles demonstrated by mtDNA sequence analysis. Ecol Appl 8:1-7

> Brongersma LD (1968) Notes upon some turtles from the Canary Islands and from Madeira. Verh K Ned Akad Wet C 71:128-136

Brongersma LD (1972) European Atlantic turtles. Zool Verh 121:1-318

Brongersma LD (1982) Marine turtles of the eastern Atlantic Ocean. In: Bjorndal KA (ed) Biology and conservation of sea turtles. Smithsonian Institution Press, Washington, DC, p 407-416

Caldwell DK (1968) Baby loggerhead turtles associated with Sargassum weed. J Fla Acad Sci 31:271-272

- Carr AF (1986) Rips, FADs and little loggerheads. Bioscience 36:92-100

Carr AF (1987) New perspectives on the pelagic stage of sea turtle development. Conserv Biol 1:103-121

CLS America (2007) ARGOS user's manual: worldwide tracking and environmental monitoring by satellite [October 14, 2008 update]. ARGOS, Toulouse. Available at: www.argos-system.org/manual/index.html\#home.htm (accessed October 1, 2010)

Davenport J, Scott CR (1993) Individual growth and allometry of young green turtles (Chelonia mydas L.). Herpetol J 3:19-25

Dougherty E, Rivera G, Blob R, Wyneken J (2010) Hydrodynamic stability in posthatchling loggerhead (Caretta caretta) and green (Chelonia mydas) sea turtles. Zoology 113:158-167

> Fossette S, Corbel H, Gaspar P, Le Maho Y, Georges JY 
(2008) An alternative technique for the long-term satellite tracking of leatherback turtles. Endang Species Res $4: 33-41$

Frick J (1976) Orientation and behaviour of hatchling green sea turtles (Chelonia mydas) in the sea. Anim Behav 24: 849-857

- Girard C, Tucker AD, Calmettes B (2009) Post-nesting migrations of loggerhead sea turtles in the Gulf of Mexico: dispersal in highly dynamic conditions. Mar Biol 156: 1827-1839

> Hays GC, Marsh R (1997) Estimating the age of juvenile loggerhead sea turtles in the North Atlantic. Can J Zool 75: 40-46

Hays GC, Akesson S, Godley BJ, Luschi P, Santidrian P (2001) The implications of location accuracy for the interpretation of satellite-tracking data. Anim Behav 61:1035-1040

Hays GC, Fossette S, Katselidis KA, Mariani P, Schofield G (2010) Ontogenetic development of migration: Lagrangian drift trajectories suggest a new paradigm for sea turtles. J R Soc Interface 7:1319-1327

Heppell SS, Crouse DT, Crowder LB, Epperly SE and others (2005) A population model to estimate recovery time, population size and management impacts on Kemp's ridley sea turtles. Chelonian Conserv Biol 4:767-773

Holm ER, Orihuela B, Kavanagh C, Rittschof D (2005) Variation among families for characteristics of the adhesive plaque in the barnacle Balanus amphitrite. Biofouling 21: 121-126

Hopkins-Murphy SR, Owens DW, Murphy TM (2003) Ecology of immature loggerheads on foraging grounds and adults in internesting habitat in the eastern United States. In: Bolten AB, Witherington BE (eds) Loggerhead sea turtles. Smithsonian Institution Press, Washington, DC, $p$ 79-92

Ireland LC, Frick JA, Wingate DB (1978) Nighttime orientation of hatchling green turtles (Chelonia mydas) in the open ocean. In: Schmidt-Koenig K, Keeton WT (eds) Animal migration, navigation, and homing. Springer-Verlag, Berlin, p 420-429

Jones TT, Bostrom B, Carey M, Imlach B and others (2011) Determining transmitter drag and best-practice attachment procedures for sea turtle biotelemetry studies. NOAA Tech Memo NOAA-TM-NMFS-SWFSC-480, US Dept of Commerce

Liew HC, Chan EH (1995) Radio-tracking leatherback hatchlings during their swimming frenzy. In: Richardson JI, Richardson TH (eds) Proceedings of the 12th annual workshop on sea turtle biology and conservation. NOAA Tech Mem 361:67-68

Lohmann KJ, Cain SD, Dodge SA, Lohmann CMF (2001) Regional magnetic fields as navigational markers for sea turtles. Science 294:364-366

Mansfield KL, Saba VS, Keinath JA, Musick JA (2009) Satellite telemetry reveals a dichotomy in migration strategies among juvenile loggerhead turtles in the northwest Atlantic. Mar Biol 156:2555-2570

McClellan CM, Read AJ (2007) Complexity and variation in loggerhead sea turtle life history. Biol Lett 3:592-594

Murray DL, Fuller MR (2000) A critical review of the effects of marking on the biology of vertebrates. In: Boitani FT (ed) Research techniques in animal ecology. Columbia University Press, New York, NY, p 15-64

Musick JA, Limpus CJ (1997) Habitat utilization and migration in juvenile sea turtles. In: Lutz PL, Musick JA (eds) The biology of sea turtles. CRC Press, Boca Raton, FL, p 137-163

Rittschof D (2000) Natural product antifoulants: one perspective on the challenges related to coatings development. Biofouling 15:119-127

Submitted: May 24, 2011; Accepted: November 4, 2011
Rittschof D, Orihuela B, Stafslien S, Daniels J, Christianson D, Chisholm B, Holm E (2008) Barnacle reattachment: a tool for studying barnacle adhesion. Biofouling 24:1-9

Roark AM, Bjorndal KA, Bolten AB (2009) Compensatory responses to food restriction in juvenile green turtles (Chelonia mydas). Ecology 90:2524-2534

Roberts D, Rittschof D, Holm E, Schmidt AR (1991) Factors influencing initial larval settlement: temporal, spatial and molecular components. J Exp Mar Biol Ecol 150:203-211

Salmon M, Wyneken J (1987) Orientation during the swimming frenzy period in loggerhead sea turtles. J Exp Mar Biol Ecol 109:137-153

> Seney EE, Higgins BM, Landry AM Jr (2010) Satellite transmitter attachment techniques for small juvenile sea turtles. J Exp Mar Biol Ecol 384:61-67

Sherrill-Mix S, James M (2008) Evaluating potential tagging effects on leatherback sea turtles. Endang Species Res 4: 187-193

Smith MM, Salmon M (2009) Activity and habitat selection by loggerhead (Caretta caretta L.) and green turtle (Chelonia mydas L.) hatchlings: a laboratory and field study. Mar Turtle Newsl 126:9-13

Stewart KR, Wyneken J (2004) Predation risk to loggerhead hatchlings at a high-density nesting beach in Southeast Florida. Bull Mar Sci 74:325-335

Stokes L, Wyneken J, Crowder LB, Marsh J (2006) The influence of temporal and spatial origin on size and early growth rates in captive loggerhead sea turtles (Caretta caretta) in the United States. Herpetol Conserv Biol 1: $71-80$

Tougaard J, Teilmann J, Tougaard S (2008) Harbour seal spatial distribution estimated from Argos satellite telemetry: overcoming positional errors. Endang Species Res $4: 113-122$

Troëng S, Solano R, Díaz-Merry A, Ordoñez J and others (2006) Report on long-term transmitter harness retention by a leatherback turtle. Mar Turtle Newsl 111:6-7

Turtle Expert Working Group (2000) Assessment update for the Kemp's ridley and loggerhead sea turtle populations in the western North Atlantic. NOAA Tech Memo NMFS-SEFSC-409, US Dept of Commerce

> Watson KP, Granger RA (1998) Hydrodynamic effect of a satellite transmitter on a juvenile green turtle (Chelonia mydas). J Exp Biol 201:2497-2505

Whelan CI, Wyneken J (2007) Estimating predation levels and site-specific survival of hatchling loggerhead sea turtles (Caretta caretta) from South Florida beaches. Copeia 2007:745-754

- Wilson RP (2011) Animal behaviour: the price tag. Nature 469:164-165

Witherington BE (1995) Observations of hatchling loggerhead turtles during the first few days of the lost year(s). In: Richardson JI, Richardson TH (eds) Proceedings of the 12th annual workshop on sea turtle biology and conservation. NOAA Tech Mem NMFS-SEFSC-361, US Dept of Commerce, p 154-157

Witherington BE (2002) Ecology of neonate loggerhead turtles inhabiting lines of downwelling near a Gulf Stream front. Mar Biol 140:843-853

Witherington BE, Salmon M (1992) Predation on loggerhead turtle hatchlings after entering the sea. J Herpetol 26: 226-228

Wyneken J, Salmon M (1992) Frenzy and post-frenzy swimming activity in loggerhead, green, and leatherback hatchling sea turtles. Copeia 1992:478-484

> Wyneken J, Madrak SV, Salmon M, Foote J (2008) Migratory activity by hatchling loggerhead sea turtles (Caretta caretta L.): evidence for divergence between nesting groups. Mar Biol 156:171-178

Proofs received from author(s): March 21, 2012 